\title{
状態変数パターン評価のためのニューラルネット 構築手法の検討
}

$\begin{array}{llllll}\text { 正員 } & \text { 西 } & \text { 村 } & \text { 和 } & \text { (東 芝) } \\ \text { 正員 川 } & \text { 崎 } & \text { 美 } & \text { 穂 } & \text { (東 芝) } \\ \text { 正員 島 } & \text { 田 } & & \text { 毅 } & \text { (東 芝) }\end{array}$

\author{
Methods to Build Neural Networks for Evaluation of State Variable Patterns \\ Kazuo Nishimura, Member, Miho Kawasaki, Member, Tsuyoshi Shimada, Member (Toshiba \\ Corp.)
}

Evaluation of system state is becoming imperatively important in supervising and controlling huge systems such as power generation and transmission systems, and industrial plants.

In this paper, the authors discuss two methods to build the neural networks for the purpose. One is based upon backpropagation and the other is a new method proposed by the authors. Unlike backpropagation which forms the completely distributed activation structure of neurons, the proposed method enables self-organization of the modules which are activated selectively to an input pattern. The new method not only makes biologically natural structure of neural network but also shortens considerably the learning time by localizing the links to be updated in the learning process.

キーワード：ニューラルネット、バックプロパゲーション. LVQ, パターン認識, 系統監視

\section{1.まえがき}

近年, 遂次形計算機を強化・補完する計算機システ ムとして，単純な素子の集合体による並列演算が脚光 をあびている。特に，生体の神経網を模擬した神経回 路網演算装置(ニューラルネットワーク, neural net work, 以下, NN と略記) は, 学習能力, 高速性, 信頼性などの特徽が指摘されている。これらの特徵の うち，現在特に注目されているものはその学習能力て あり，この能力を種々の応用に有効利用する試みが各 所においてなされている(1)。

本墖文は，電力系統や工業プラントに拈いて，状態 変数パターンから，その時点でのシステムの状態を評 洒するNNを考え，このような目的に用いるNNを 啭築するための，新しい手法を提案するものである。

従来の構筑手法としては，Rumelhartによるバッ クプロパゲーション (Backpropagation, 以下, BP
と略記）を学習アルゴリズムとして，3層の NNを 構築する手法が広、用いられているが，この手法で は，ある入力パターンに対して活性化されるニューロ ン群が広く分散して，特定の領域に限定されない。こ れに対して，提案する手法はNN内にモジュール化 された活性領域を生成するものであり，上記の手法の 実用上の問題である膨大な学渂時間を短縮することを 目的として開発した手法である。

そして，このようなモジュール構造によって学習に おける重み修正が局所化されるため, 高速な NNの 構築が可能となる。

本論文では, 状態変数パターン評価システムとし て, 電力系統に拈ける電圧パターンからその系統の電 圧状態に専門的な評価を与えるシステムを題材とし， 上記二種類の手法を学習性能と補間性能について比較 する。 


\section{2. 学習によるニューラルネットワークの自己 組織化}

NN は生体の神経網を模擬したものでニューロン の集合体である。ニューロンはュニットとも呼ばれ， 本論文では主にユニットと呼ぶものとする。以下に述 ぶるとおりの NN 構築手法は共に入力ユニット群 (入力層), 中間ュニット群 (中間層), 出力ュニット群 (出力層) からなるネットワークを対象とする。NN における学習とは, NNが望ましい入出力関係を実現 するようにユニット間の結合の大きさを調整すること であるが，これは望ましい入出力信号をNNに繰返 し印加することによって見掛け上自然形成される。こ の過程は，NNが与えられた入出力信号に对して，そ の組織を自己形成するかのように見えるので，これを 以下，学盟による自己組織化と呼ぶもとする。

本論文では，学習による自己組織化を二種類に分け て検討している。一つは，実現されるNNにおいて， ある入力信号に対する活性化ユニットが分散している ものである。従来の BP は、このような自己組織化が なされる学習手法である。この自己組織化は，いわば 非晶筫的な NN を実現するものである。以下では， これを分散活性構造への自己組織化と呼ぶ。

これに対して，提案する $\mathrm{NN}$ 構築手法は，ある入 力信号に対して選択的に反応する部分領域の集まりと してNNが自己組織化されることを目指すものであ る。例え壮人間の視賞神経系が特徵ごとに選択的に反 応する細胞群によってできている事夷などに照らす と，この手法のほうが自然である。上述の非晶質的 NNに向かう自己組織化に対して，この自己組織化は モジュール構造へ向かうものなので，以下これをモジ ユール構造への自己組織化と呼ぶものとする。

$\langle 2 \cdot 1\rangle$ 分散活性構造への自己組織化この自己 組織化を行うNN 構築手法として本論文で扱うのは BPに基づく手法であるが，BPは既によく知られて おり,ここでは要点のみ述べる。BPで扱う NNで は, ユニットjの出力注次式で表される。

$$
\begin{aligned}
& v_{j}=f_{j}\left(\sum_{j \neq i} w_{j i} v_{i}-\theta_{j}+I_{j}\right) \\
& \text { ここで, } v_{i} \text { : 他ュニット } i \text { の出力, } w_{j i}: \text { ユ } \\
& \text { ニット } i \text { の出力がユニットjに及ぼす影響を } \\
& \text { 示す重み係数， } \theta_{j} \text { : しきい值， } I_{j} \text { : 外部入力 }
\end{aligned}
$$

$f_{j}$ としては, 通常 $S$ 字形の特性を用いる。学習では 望ましい出力, すなわち教示パターンと, 実際の出力 パターンとで定義される次の誤差関数を用いて重みを 修正する。

$$
E=\frac{1}{2} \sum_{j}\left(t_{j}-v_{j}\right)^{2}
$$

ここで，tと， $v_{j}$ はそれぞれ出力ュニットjへの教示 データ（望ましい出力）およびそのユニットの出力で ある。これより，Eを小さくする重み係数の修正量 $\Delta w_{i j}$ は次式によって計算さ机る。

$$
\begin{aligned}
& \Delta w_{i j}=-\eta \frac{\partial E}{\partial w_{i j}} \cdots \cdots \cdots \ldots \ldots \ldots \ldots \\
& \text { ここで, } \eta: \text { 学習率を示す正の数 }
\end{aligned}
$$

入力パターンは教示データ $\left\{t_{j}\right\}$ と対にして指定さ れ,これによってNNへの入出力パターンの対応付 けがなされる。NNの著しい特幑は, 複数の入力パタ ーンと出力パターンとを関連づけることである。

〈2・2〉 モジュール構造への自己組織化 モジュ 一ル構造への自己組織化がなされる NN 構築手法と $し て ，$ 著者らは Kohonen の LVQ (Learning Vector Quantization, バクトル量子化) ${ }^{(2)} に$ におる重み修正 規則と，活性化ュニット間のリンク強化とを組合せ た。対象となる $\mathrm{NN}$ は図 1 に示すものであり，LVQ は入力層と中間層間リンクの学習に, 活性化エニット 間りンクの強化は中間層と出力層間リンクの学習に適 用される。LVQは，代表として与えられる入力パ夕 一ン群に対して, 選択的反応領域を中間層に形成す る。活性化ユニット間リンクの強化は，この反応領域 と教示パターンとを関連付けるものである。LVQで は入力量は心゙クトル $x$ として报い，

$$
x=\operatorname{col}\left(x_{1}, x_{2}, x_{3}, \cdots, x_{n}\right)
$$

とする。また，各入力ュニット $(i=1 \sim n)$ 加ら中

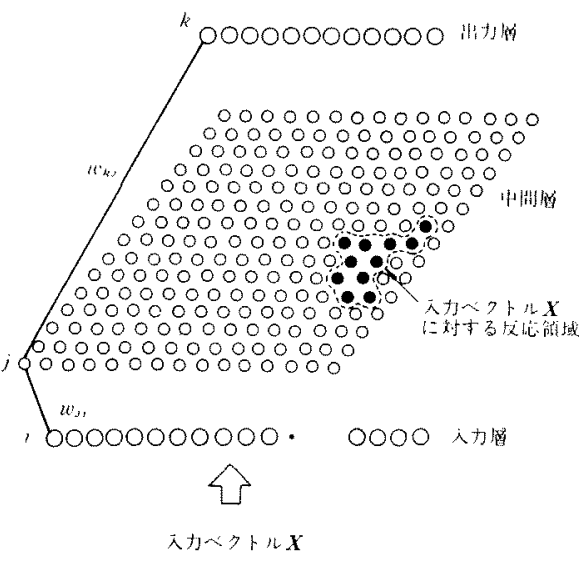

図 1 ニューラルネットワークの構成 (SOMA)

Fig. 1. Structure of neural network (SOME). 
間ユニット $j$ への重み $w_{j i}$ もべタトル

$$
m_{j}=\operatorname{col} .\left(w_{j 1}, w_{j 2}, w_{j 3}, \cdots, w_{j n}\right)
$$

を構成するとする。そして，以下の学習を繰返す。

（1）与えられた入力ベクトルに最も近い重みべク トル $m_{c}$ を求める。すなわち,

$\left\|m_{c}-x\right\|=\min \left\|m_{j}-x\right\|$

(2) $m_{c}$ に対応する中間ユニット $u_{c}$ を中心とし た半径 $r$ 領域を近傍 $N_{c}$ とする。

$$
N_{c}=\left\{u_{j} \mid d\left(u_{j}, u_{c}\right) \leqq r\right\}
$$

(3) $N_{c}$ 内のユニット $u_{j}$ について, リンク荷重べ タトル $m_{j}$ を更新する。

$$
\Delta m_{j}=\alpha\left(x-m_{j}\right) \quad(\alpha: \text { 学習率 })
$$

(4) 入力ベクトルを変えて（1）に居る。

ここで, 半径 $r$ と学習率 $\alpha$ は絽返しが進むにつれ て減少させる。また，入力ベタトルは代表べタトルを 順番に何回も教示する。LVQによって中間層の選択 的反応領域形成が終了した後，中間ユニットjと出力 ユニット $k$ 間の重み係数 $w_{k j}$ の学習を次式に従って 行う。

$$
\Delta w_{k j}=\beta\left(T_{k}-O_{k}\right) A_{j}
$$

ここで， $T_{k}$ と $O_{k}:$ それぞれ出力ュニットk

の教示信号抢よじ出力， $A_{j}$ : 中間ュニットj

の出力, $\beta$ : 学習率

あるパターンに対する中間層の活性領域は局部化され ているため，この部分の学習は高速に行われる。 $O_{k}$ は次の式で与えるものとし，後述の例では $A, か ゙ 0.6$ 以上のものを加算の対象としている。

$$
O_{k}=\sum_{j} w_{k j} A_{j}
$$

LVQにおける中間ユニットの入出力特性は，通常 の BPで利用している $\mathrm{S}$ 字形関数とは異なり，入力 ベクトルと重みベクトルの近さを反映するものでなけ ればならない。本検討では次式の特性を仮定した。

$$
A_{j}=1 /\left(\left\|m_{j}-x\right\|+1\right)^{4}
$$

以上の $\mathrm{NN}$ 構築手法では，BP と同様にパターン教 示の繰返しによって入出力特性を形成できる。BPと 異なる点は，BP が出力啌差を多数のリンクの重み修 正にフィードバックさせているのに対し，この手法で は，あるパターンに対して活性度の高い領域が形成さ れ，その領域に沿った伝搬経路を構成するリンクが強 化されることである。このNN 構築手法は，前述の モジュールへの自己組織化を活性度伝搬領域に沿って の重み修正によって奏現する手法なので, 本論文では SOMA (Self-Organization to Modules by Activity propagation）と呼んでBPに基づく構築手法と区別 することにする。以下，電力系統の電圧パターン評価
システムを題材として，これらの学習方法の学習性能 や補間性能について検討する。

\section{3. 電力系統の状態評価システム}

状態変数パターンの評佂システムの例として本論文 で扱う電力系統の状態評価システムは, 筆者らが提案

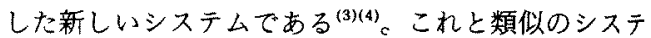
ムとして，系統の緊急時に大量に発生するアラームの 内容を整理して，操作岛が系統状態を把握することを 支援する装置（アラームプロセッサ）が考えられてお り，これを知識工学に基づいて実現しようという試み があるが，提案するシステムはこのようなシステムと 同様の目的をもつ。異なる点は，提案するシステムて はアラーム情報を整理するのではなく，状態量のパ夕 ーンから直接評価内容を与えることである。またこ のシステムは系統の安定度などを緊急時のみならず常 時監視することも目的とする。なお，系統の状態量と しては，電圧，通過電力，相差角など考えられるが， 本検討はとりあえず電圧のみを対象としている。

本検討では 35 ノードのモデル系統を仮定し，その うち 25 ノードにおいて電圧が観測されるものとする。 また，その系統で 14 個の代表的電压パ夕ーンを仮定 する。図 2 にその一例を示す。電压は1.0 puからの 偏差で表している。更に，これらのパターンに対する 評価内容を表 1 のよう仮定する。表中の丸印は，各 パターンに対して成立する評価項目を示す。例えに゙， パターン11 峘間の電圧パターンで, 系統の北東部 において電圧が異常低下していることを示している。 電圧パターンは潮流計算で作成したが，実際の系統で は，代表的な電圧パターンは系統の運用実積から求め る必要があり，またそれらのパターンに対する評価も 系統解析と経験的蓄積から行う必要がある。NNによ

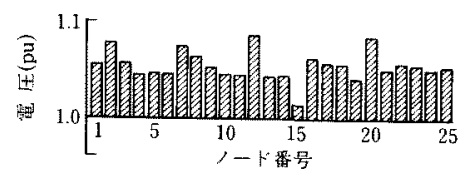

(a)パターン1(健全)

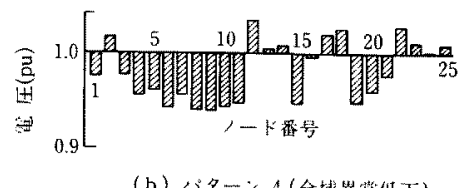

図 2 代表電圧パターンの例

Fig. 2. Example of typical voltage pattern. 
表 1 代表電圧パターンに対する評価項目

Table 1. Evaluation items for typical voltage patterns.

\begin{tabular}{|c|c|c|c|c|c|c|c|c|c|c|c|c|c|c|}
\hline 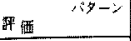 & 1 & 2 & 3 & 4 & 5 & 6 & 7 & 8 & 9 & 10 & 11 & 12 & 13 & 14 \\
\hline 1，墨間 & 0 & 0 & 0 & 0 & 0 & 0 & Q & 0 & 0 & 0 & 0 & 0 & 0 & 0 \\
\hline 2. 夜間 & & & & & & & & & & & & & & \\
\hline 3，健全笔压 & 0 & & & & . & & & & & & & & & \\
\hline 4，や低下 & & 0 & & & & & & & & & & & & \\
\hline 5. 低下 & & & 0 & & 0 & 0 & 0 & 0 & & & & & & \\
\hline 6，異常低下 & & & & 0 & & & & & 0 & 0 & 0 & 0 & 0 & 0 \\
\hline 7. 北東部 & & & & & & & 0 & & & & 10 & & & \\
\hline 8，北西部 & & & & & & & & 0 & & & & 0 & & \\
\hline 9，南東部 & & & & & & 0 & & & & 0 & & & & 0 \\
\hline 10. 南西部 & & & & & 0 & & & & 0 & & & & 0 & \\
\hline 11．重色荷 & & & & & & & & & & & & & 0 & 0 \\
\hline 12. 全域 & 0 & 0 & 0 & 0 & & & & & & & & & & \\
\hline
\end{tabular}

るパターン情報の処理には，学習による知識の䔟入が でき知識の厳密な記述が不要, データの全体的な把握 がなされる, 若干の知識変更に対する再学甶性, 耐雑 音性，補間機能などの利点が期待されるが，本論文で は，学習性能と補間性能について上記の二と㧍りの $\mathrm{NN}$ 構築技術の比較をする。

\section{4. 学習性能}

〈4・1〉 BPに基づく場合ＮNは図 $30 も の を$ 用いた。また，入力形式は図 4 に示す方法を用いた。 この方法では 0.93〜1.03 puまでの電压を $0.01 \mathrm{pu}$ 幅 で10段階に雄散化し，ノード番号とこの電压籁囲で メッシュを作る。NNの入力層では，このメッシュ 1 個に入力層のユニット 1 個を割り当てる。電圧を観測 するノードは, 全 35 ノードから発電耭ノードを除く 25 ノードであり，入力ユニット数は 250 個となる。 離散幅はやや粗いが、今回の険討目的には十分であ る。図 4 の入力形式では $1.0 \mathrm{pu}$ を基準電圧として, この基準電圧とノード電圧の間に存在するユニットを 活性化させる。

中間ュニット数は 10 または 20 , 出力ュニット数は 12 である。出力ュニットは表 1 の 12 個の評洒項目に 対応する。表 1 の評価項目のうち，成立項目は 1.0 , 不成立は 0.0 として教示パターンを作り，パターン 1 からパターン14 の順で教示を繰返した。中間ュニッ 卜が 10 個のとき, 約 20,000 回で学習が完了した。学 習は最も取束しにくいパターンに扔いて出力值が教示 值 1.0 k対しては 0.7 以上，教示值 0.0 に対しては 0.3 以下になるまで行った。計算時間は 32 ビットの

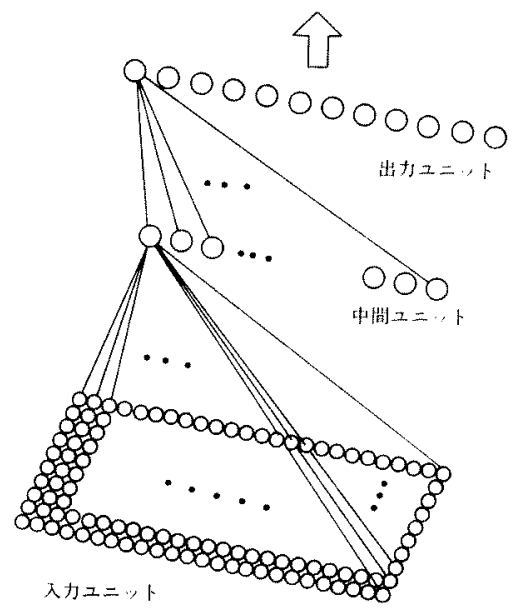

図 3 ニューラルネットワークの構成 (BP)

Fig. 3. Structure of neural network (BP).

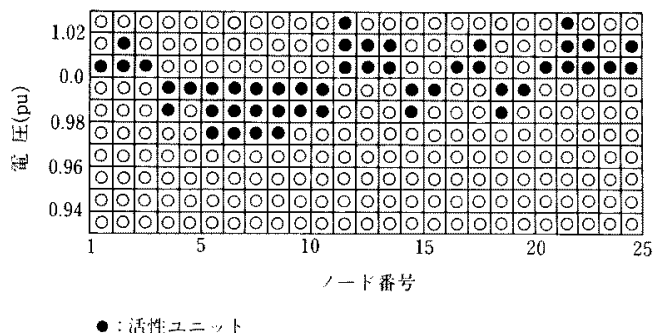

図 4 ニューラルネットワークへの入力形式

Fig. 4. Input data form to neural network.

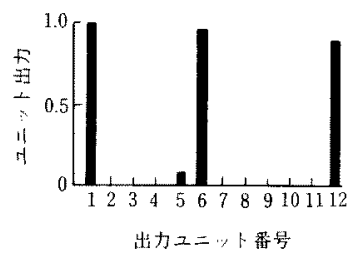

図 5 ニューラルネットワークの出力例 (BP)

Fig. 5. Example of output from neural network (BP).

小形コンピュータで 150 分程度要した。NNの出力の 一例を図 5 に示す。

次に，学習回数と中間ュニット数との関係について も調ベたが，それによれば中間ユニットが多いほど必 要な学習回数は隇少する。これは1回の学習で修正さ れる重みの数が増加することによって出力誤差の低下 
量が大きくなるためであるが，学垍回数 1 回あたりの 計算時間も中間ユニット数にほほ比例して増加するた め, 全計算時間という点ではほとんど変わらない。た だし，中間ユニット数がある程度以下（ここでは6） になると必要な学習回数および全計算時間は急激に増 加した。また，図 3 以外の入力形式についても倹討し たが，パターン間の特徽が薄められる入力形式の場合 ほど学習回数は増加した。

〈4・2〉SOMAによる場合採用したNNの構 造は既に図 1 に示したものである。この埸合は, 各 ード電生偡をアナログ值の文ま 25 個の入力ユニット に入力する。各ノード電圧は $0.9 \mathrm{pu}$ 加らの偏差で表 す。中間ユニットの数は特に断らない限り $15 \times 15$ 個 である。出力ュニットは 12 個で表 1 の評洒項目に対 応する。図 6 岵学習済みNNに代表電圧パターンを 入力したときのNNの状態例であるが，ある代表パ ターンに対して中間層の一群のニニットが選択的に反 灾している。各パターンに対する反応領域の位置は外 部から指定するのではなく，LVQによって，代表パ ターンの繰返し教示によって自然に生成される。活性 図の横に示される 12 個の項目は出力ユニットの出力 である。入力層と中間層間の学照は選択的反応領域が 形成されるに従い効率が落ち, 中間層と出力層間の学 習は選択的反応領域が形成されるまでは効率が低いの で，今回用いたプログラムではこれらの二とおりの絽 返し学習は特に分離せず，同時に行ったが，出力層に 抬ける 2 乗愦差総和が 0.0001 以下となることを学習 収束の基準にした場合，教示回数約 840 回を要し，約 16 分で収束している。BPによる場合にはすべてのパ ターンの区別が明確にできるまでに約 150 分かかって いるので，以上の結果より対象とした問題に関する限

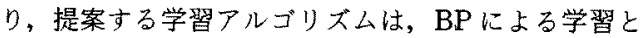

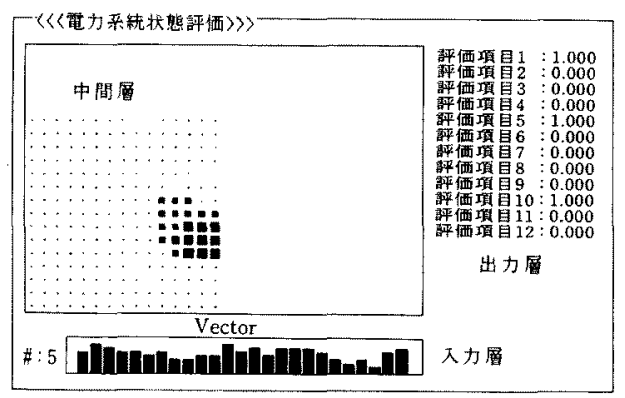

図 6 ニューラルネットワークの出力例 (SOMA)

Fig. 6. Example of output from neural network (SOMA).
比べて 10 倍近く高速である。

学習過程はリンクに付随する重み係数の修正の繰返 しなので，ネットワークの規模については，計算時間 という観点からはリンク数がおおよその目安を与え る。雨手法で扱うホットワークの形や入力方式は, 今 回の目的に対して同程度の良好な性能を示すように， それぞれの手法ごとに試行的に決められ，厳密にリン ク数が同じになるような工夫はしていないが，今回の 検討では，BPによるもののリンク数は 5,240 本, SOMAによるものは 8,325 本となっており, 同程度 の規模のネットワークと考えてよい。BPては上記の リンクのすべてが修正対象となるのに対して, SOMA では今回の例ではリンク数はやや多いものの， 選択的反応領域の形成後は実際の修正対象となるリン ク数が滅少するため, 計算時間が短縮される。

計算時間はネットワークの大きさにもよるため，中 間ユニット数を変えて計算時間を調ベた。中間ユニッ 卜を増やすにつれて計算時間はやや増加する傾向にあ るが，BPの場合と同様に中間ュニットが增すにつれ て必要な教示回数は減るので，この計算時間の増加は 顕著なものではない。SOMAの場合には代表パター ンの識別能力は，中間簤を大きくするほど向上し，代 表パターンのうち最も類似する二つのパターンによっ て必要な中間層の大きさが決まる。

\section{5. 補間性能}

補間性能は，代表的なパターンとしてあらかじめ想 定していなかったような状態量パターンが発生した場 合に，そのパターンに類似した複数の代表パターンの 合成としてその状態量パターンの特幑を表現する能力 である。補間性能を調べるために, 本研究では二つの 代表的パターンをある比率で混合させたパターンを作 り，それに対するNNの応答を調ぺた。混合パター ンとしては次の代表パターンによるものを用いた。

(1) 全域やや低下 (パターン2) と

異常低下 (パターン4)

（2）北東部低下 (パターン7) と 北西部低下 (パターン 8)

〈5・1〉全域電压やや低下と異常低下 BP およ び SOMAの場合について，パターン2「全域電圧や や低下」と，パターン4「全域電圧異常低下」の混合 パターンに対する出力を図 7 に示す。BPでは中間二 ニットが 10 個よりも20 個の場合のほうが補間性能は 良好であったので，ここではその結果を示す。また， SOMA の場合には中間層が $10 \times 10$ と $15 \times 15$ につい て検討したが, 結果が良好であった後者について示し 
ている。BP と SOMA とでは NN 構造が異なるため に特性は若干異なるが, ともに電圧低下の大きさを示 出出カユニット $4,5 ， 6$ は，4 加 6 へ出力の大きさ が連続的に移行して扔り,人間の感賞と一致する良好 な補間性能となっている。

〈5・2〉北東部低下と北西部低下 この例ではパ ターン 8 「北西部電圧低下」にパターン 7 「北東部電 圧低下」を混合し，パターン 8 の特徴が次第に薄れて いくときのNNの応答に着目する。BPおよび SOMA の場合について, NN の入出力特性を図 8 に 示す。混合比率が $4: 1$ のときには, 北西部低下パ夕
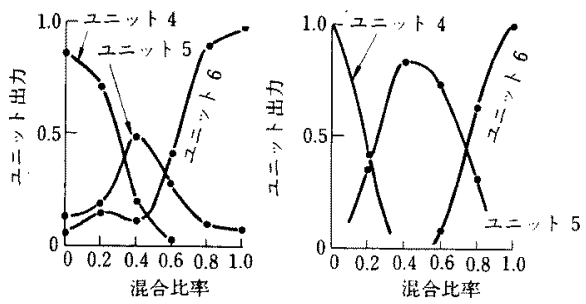

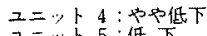

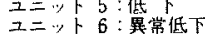
(a) $\mathrm{BP}$
(b) SOMA

図 7 電压に関する補間特性

Fig. 7. Interpolation between different typical patterns in voltage reduction.
ーンが北東部低下パターンによって変わいを受けてい るが、パターンとしての全体的特徽は北西部低下パ夕 ーンのものを保持しているので, 大きな出力を出して いるユニットは混合比率が 1：00場合と変わらない。 混合比率が $3: 2$ の場合には, BP の場合もSOMAの 場合もパターン１「健全」への引込みが見られるが, これはパターンの類似性という点では適切である。し かし, 電力系統制御の専門家であれば, 全体的には健 全状態に近いパターンではあっても，重大な結果が引 起こされるかも知れない北西部の電圧低下に近い状態 として,一応パターン 8 との類似性に着目すると考え られる。そしてこのような判断には, 単なる形状的な 類似性のみならず, 論理的な解积を伴う。この点にお いて現在の NN は專門家の補間能力の一部にすぎな い。この結果より，提案するSOMA B BP の場合と ほぽ同程度の補間性能をもつことがわかる。

\section{6. まと め}

以上，電力系統における電圧パターンの認識を題材 として，BPおよび提案する手法によって構築した NNの性能について実験的に検討をした。これによれ ば, BPに基づいて構築した $\mathrm{NN}$ は, 中間ユニット数 や入力形式を適切に設定すれば，パターンとして与え られる知識の処理に有効である。しかしながら，BP は学習のために膨大な計算時間を必要とし,これが大
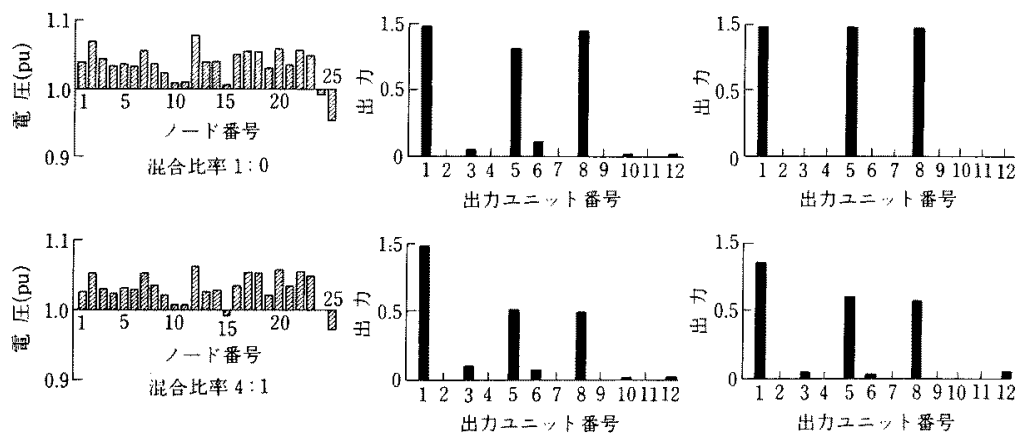

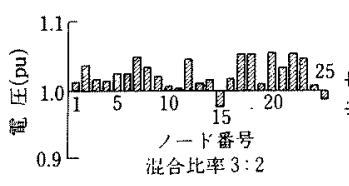

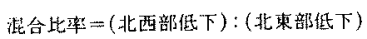

(a) 笛压パターン

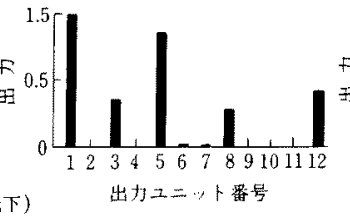

(b) NN出力(BP)

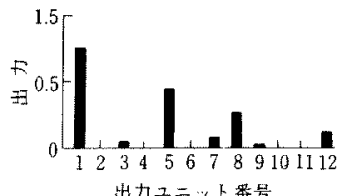

(c) NN出力(SOMA)

図 8 場所に関する補間特性

Fig. 8. Interpolation between different typical patterns in area. 
規模なシステムへの適用において大きな障害となり得 る。この問題を解決するために提案した NN 構築手 法は, ある入力パターンに対して選択的な反応領域が 中間層に形成されるものであり, BPによる NN が活 性領域にモジュール性のない分散活性構造であること と対照的である。このようなモジュール性をもつこと によって，学習における重み修正が局所化されるた め, 提案する手法は, 今回検討した例では, 学習速度 はBPに比べて一けた近く高速になっている。また， 代表パターン以外の入力に対する補間特性も BP の場 合と同程度であり，少なくとも今回検討対象としたよ うな適用分野では, $\mathrm{BP}$ に劣らない実用性能が期待で きる。

しかしながら，BPにおいても提案する手法におい ても，論理的な解釈や，その基礎となる事例からの一 般化能力は十分とは言えない。実用化において高度な 性能を得るには, 今後, 事例からの一般化や論理の導 入などの研究が必要と考えられる。

(平成元年 2 月 28 日受付, 同元年 9 月 13 日再受付)

\section{文献}

(1) R. Hecht-Nielsen: "Neurocomputing : picking the human brain", IEEE Spectrum, p. 37 (1988)

(2) T. Kohonen: "Learning Vector Quantization for pattern recognition", Report TKK-F-A601, (1986) Helsinki Univ. of Tech.

(3) 西村：「ニューラルネットの電力系統への適用に関する考 察」, 電気学会システム・制御研資, SC-88-10 (昭 63)

（4）西村,川崎:「ニューラルネットワークによる状態変数パ ーンの評価システム」, 電気学会情報処理研資, IP-88-2 (昭 63)

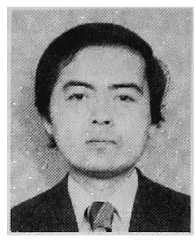

西 村 和夫（正員）

昭和 26 年 9 月 12 日生。 54 年 3 月東京大学大学院電気工学専門課程 博士課程修了。工学博士。同年 4 月

(株) 東芝入社。重電技術研究所にお いて電力系統工学の研究に従事。6 62 年より(株)東芝 システム・ソフトウェア技術研究所において分散制御, ニューラルネットワークに関する研究に従事。IEEE, International Neural Network Society 会員。

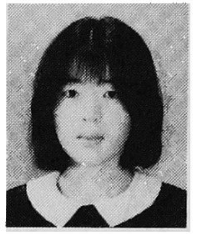

\section{川崎 美 穂（正員）}

昭和 39 年 12 月 31 日生。 62 年 3 月東京農工大学工学部数理情報工学 科卒業。同年 4 月 (株) 東芝入社。以 来システムソフトウェア技術研究所 にて, ニューラルネットワーク, マンマシンインタフ エースの研究に従事。

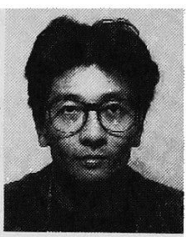

\section{島 田毅（正員）}

昭和 37 年 6 月 3 日生。 63 年 3 月 北海道大学大学院文学研究科行動科 学専攻修士課程修了。同年 4 月 (株) 東芝入社。現在システム・ソフトウ エア技術研究所において神経回絡網技術の研究に従 事。INNS 会員。 